\title{
Gaucher disease and the synucleinopathies: refining the relationship
}

Tessa N Campbell ${ }^{1}$ and Francis YM Choy ${ }^{2^{*}}$

\begin{abstract}
Gaucher disease (OMIM 230800, 230900, 231000), the most common lysosomal storage disorder, is due to a deficiency in the enzyme glucocerebrosidase. Gaucher patients display a wide spectrum of clinical presentation, with hepatosplenomegaly, haematological changes, and orthopaedic complications being the predominant symptoms. Gaucher disease is classified into three broad phenotypes based upon the presence or absence of neurological involvement: Type 1 (non-neuronopathic), Type 2 (acute neuronopathic), and Type 3 (subacute neuronopathic). Nearly 300 mutations have been identified in Gaucher patients, with the majority being missense mutations. Though studies of genotype-to-phenotype correlations have revealed significant heterogeneity, some consistent patterns have emerged to inform prognostic and therapeutic decisions. Recent research has highlighted a potential role for Gaucher disease in other comorbidities such as cancer and Parkinson's Disease. In this review, we will examine the potential relationship between Gaucher disease and the synucleinopathies, a group of neurodegenerative disorders characterized by the development of intracellular aggregates of $\alpha$-synuclein. Possible mechanisms of interaction will be discussed.
\end{abstract}

Keywords: Gaucher disease, glucocerebrosidase, GBA mutations, lysosomal storage disease, synucleinopathies, Parkinson's disease, dementia with Lewy bodies, multiple system atrophy, neurodegeneration with brain iron accumulation, protein misfolding

\section{Review}

\section{Overview of Gaucher Disease}

Gaucher disease (OMIM 230800, 230900, 231000), the most common lysosomal storage disorder, is characterized by a spectrum of signs and symptoms caused by the defective hydrolysis of glucocerebroside. A deficiency in the enzyme glucocerebrosidase (GBA, glucosylceramidase, acid $\beta$-glucosidase, EC.3.2.1.45) leads to the accumulation of its glucocerebroside substrate in the liver, spleen, and bone marrow. The predominant symptoms are hepatosplenomegaly, haematological changes, and orthopaedic complications [1,2]. Gaucher disease has been classified into three phenotypes based upon the presence or absence of neurological involvement: Type 1 (non-neuronopathic; most common form), Type 2 (acute neuronopathic) and Type 3 (subacute neuronopathic) [3].

\footnotetext{
* Correspondence: fchoy@uvic.ca

2Department of Biology, University of Victoria, PO Box 3020, Station CSC, Victoria, BC, V8W 3N5, Canada

Full list of author information is available at the end of the article
}

The GBA gene, located on chromosome 1q21-22, is comprised of 11 exons encoding a 497 amino acid protein. Presently, nearly 300 mutations have been identified in Gaucher patients, including frame-shift mutations, point mutations, deletions, insertions, splice site mutations, and recombinant alleles $[2,4,5]$. For the purpose of genotype-phenotype correlations, many of these mutations have been classified as "null," "severe," or "mild" with respect to levels of glucocerebrosidase production. Null mutations, such as c.84dupG (84 GG), do not direct any enzyme production. Severe mutations, such as c.1448T > C (L444P), produce enzyme but, when inherited with a null or another severe mutation, are usually associated with Type 2 or 3 disease. Mild mutations, such as c.1226A > G (N370S), are those that are only associated with Type 1 disease [6].

Gaucher disease is the first lysosomal storage disorder to be successfully treated by enzyme replacement therapy [7]. At present, alglucerase (Ceredase ${ }^{\circledR}$, Genzyme Inc.), imiglucerase (Cerezyme ${ }^{\circledR}$, Genzyme Inc.), and velaglucerase alfa (VPRIVTM, Shire) have been FDA-approved for
C Biomed Central

(ㄷ) 2012 Campbell and Choy; licensee BioMed Central Ltd. This is an Open Access article distributed under the terms of the Creative Commons Attribution License (http://creativecommons.org/licenses/by/2.0), which permits unrestricted use, distribution, and reproduction in any medium, provided the original work is properly cited. 
treatment of Gaucher patients [8,9]. Alternative therapies have also been developed. In 2003, substrate reduction/ inhibition therapy (miglustat, Zavesca ${ }^{\circledR}$, Actelion Pharmaceuticals) was FDA-approved for adult patients unsuitable for enzyme replacement therapy [10]. Other treatment avenues under exploration are stabilization of the mutant lysosomal protein through chaperone therapy and introduction of wildtype glucocerebrosidase genes through gene therapy [11].

Recent research has highlighted a potential role for Gaucher disease in other comorbidities such as cancer and Parkinson's disease. In this review, we discuss the emerging relationship between Gaucher disease and the synucleinopathies, a group of neurodegenerative disorders characterized by the development of intracellular aggregates of $\alpha$-synuclein.

\section{Overview of the Synucleinopathies}

The synucleinopathies encompass a group of various neurodegenerative disorders that share a common pathologic lesion comprised of aggregates of $\alpha$-synuclein protein in vulnerable populations of neurons and glia [12]. The synucleinopathies discussed in this review are Parkinson's disease, dementia with Lewy bodies, multiple system atrophy, and neurodegeneration with brain iron accumulation.

The synuclein family consists of soluble proteins characterized by an acidic carboxyl terminus and five to six imperfect repeat motifs (KTKEGV) distributed throughout the amino-terminus. The members range in length from 127 to 140 amino acids [12]. Initially described in 1988 , the first synuclein family member ( $\alpha$-synuclein) was purified from the Torpedo electroplaque and from rat brain $[13,14]$. It was also later named the nonamyloid component (NAC) of plaque precursor protein after the NAC peptide was isolated from amyloid-rich senile plaques of Alzheimer patient brains [12,14]. The $\alpha$ synuclein gene has been mapped to chromosome 4q21.3-q22 [14,15]. There are currently three additional members of the synuclein family: $\beta$-synuclein, $\gamma$-synuclein, and synoretin. The functions of the synuclein family members remain poorly understood [12].

\section{Gaucher Disease and Parkinson's Disease}

Parkinson's disease (PD) is the second most common neurodegenerative disorder, with greater than $1 \%$ affected over 65 years of age and more than $4 \%$ of the population affected by the age of 85 years $[16,17]$. Research indicates that PD likely results from a combination of polygenic inheritance, environmental exposure, and gene-environment interactions. Approximately 20\% of PD patients report a family history of the disease $[17,18]$. Traditionally, PD has been defined by the presence of classic motor signs: rigidity, tremor, bradykinesia, and postural instability. However, recent evidence indicates that nonmotor characteristics such as autonomic insufficiency, cognitive impairment, olfactory deficits, psychosis, depression, and sleep disturbance are also common occurrences [17]. The first gene (SNCA, PARK1 locus) causally linked to PD was discovered via analysis of a large multigenerational Italian family in which parkinsonism segregated in an autosomal dominant pattern $[19,20]$. Subsequently, a total of 18 PD loci (PARK 1-18) have been proposed through linkage analysis and genomewide association studies [17]. Mutations within genes at six of these loci (SNCA, LRRK2, PRKN, DJ1, PINK1, and $A T P 13 A 2)$ have been directly linked to familial parkinsonism [21]. Recently, specific variations in the Gaucher disease-associated gene $G B A$, which is not assigned to a PARK locus, have been suggested as risk factors for PD, as discussed below [22].

Over the past decade, several lines of evidence have emerged implicating an association between parkinsonism and mutations in the glucocerebrosidase gene. Recognition of the relationship between GBA mutations and PD initially began in the clinic, with the identification of rare Gaucher patients with parkinsonian symptoms appearing in case reports, larger patient series, and prospective studies [22]. Moreover, pedigree analyses indicated an elevated incidence of Parkinson's disease in relatives of Gaucher patients, many of whom were obligate heterozygotes $[23,24]$. Additionally, multiple independent studies surfaced reporting an increased frequency of $G B A$ mutations in different cohorts with parkinsonism [25-30]. Despite this evidence, early studies were often constrained by small sample sizes or evaluation of only a few common GBA mutations [31], complicating a consensus to label GBA mutations as risk factors for typical Parkinson's disease. In 2009, Sidransky et al. [22] published a hallmark study on this topic: a collective analysis of 5691 patients with PD complemented by 4898 controls from 16 centers across 12 countries. For the pool of participants in which the full GBA coding region was screened, loss-of-function mutations were observed in $6.9 \%$ of cases and $1.3 \%$ of controls (odds ratio, 5.4; 95\% CI, 3.9-7.6). Among the Ashkenazi Jewish subset, higher mutation frequencies were seen: $19.3 \%$ in cases and $4.1 \%$ in controls $[17,22]$. The findings were not exclusive to a specific ethnicity, nor associated with any particular $G B A$ mutation. Additional noted trends were: subjects carrying mutations presented an average of four years earlier, were more likely to have a family history of PD, and had less bradykinesia and rest tremor and more cognitive changes described [22]. Other cohort studies have corroborated the results from this collaborative examination, reinforcing mutations in $G B A$ as the number one genetic risk factor for PD [22,32-34]. 


\section{Gaucher Disease and Dementia with Lewy Bodies}

Like Parkinson's disease, dementia with Lewy bodies (DLB) is a common neurodegenerative condition associated with abnormal aggregations of $\alpha$-synuclein [12]. Five percent of non-institutionalized adults 85 years and older are believed to suffer from DLB, and the disease accounts for approximately $22 \%$ of all patients with dementia $[35,36]$. The fundamental features of DLB are dementia, fluctuating cognition (pseudodelerium), and visual hallucinations with Parkinsonism [36,37]. Frequently, patients with DLB have a rapid eye movement (REM) sleep behaviour disorder in the form of lively and often anxiety-filled dreams during the REM sleep phase, which may be accompanied by motor symptoms. This sleep behaviour disorder is characteristic for neurodegenerative disorders with pathological cerebral aggregates of $\alpha$-synuclein $[38,39]$.

Once the potential relationship between Parkinson's disease and Gaucher disease was evident, researchers expanded their investigations to assess whether $G B A$ mutations were associated with other Lewy body disorders, such as DLB [40]. Initial findings from Goker-Alpan et al. [41] found GBA mutations in $23 \%$ of brain samples of 35 autopsy cases with DLB. A later study screening for only c. $1448 \mathrm{~T}>\mathrm{C}(\mathrm{L} 444 \mathrm{P})$ and c.1226A $>$ G (N370S) mutations detected $G B A$ alterations in $2(3.5 \%)$ of 57 patients with DLB compared to 2 of 554 control subjects (0.4\%) [29]. Subsequent studies reported mutations in $G B A$ at frequencies ranging from $6 \%(\mathrm{n}=50)$ [42] to $28 \%$ $(\mathrm{n}=95)$ [43] of DLB cases. Collectively, these genetic studies suggest that $G B A$ mutations represent genetic risk factors for DLB [29,43]. Complementing these genetic investigations, Parnetti et al. [44] recently reported a pronounced decrease in GBA activity in cerebrospinal fluid of DLB patients. A similar reduction in GBA activity has been previously reported in PD [45]. This corroborates a relationship between Gaucher disease and the two aforementioned synucleinopathies, PD and DLB (Figure 1).

\section{Gaucher Disease, Multiple System Atrophy, and Neurodegeneration with Brain Iron Accumulation}

Multiple system atrophy (MSA), a progressive neurodegenerative disorder, is characterized by autonomic failure, poor levodopa-responsive parkinsonism, cerebellar ataxia, and various pyramidal symptoms [46]. MSA-Parkinsonism type is the most common Western Hemisphere phenotype, while MSA-cerebellar type is predominant in the Eastern Hemisphere [47]. Mean survival is approximately nine to ten years after onset of symptoms [48], with nocturnal sudden death being a major cause of mortality $[49,50]$. MSA is commonly regarded as a primary oligodendrogliopathy due to widespread glial cytoplasmic inclusions $[46,51]$. These inclusions have demonstrated immunoreactivity for $\alpha$-synuclein, thus relating MSA to

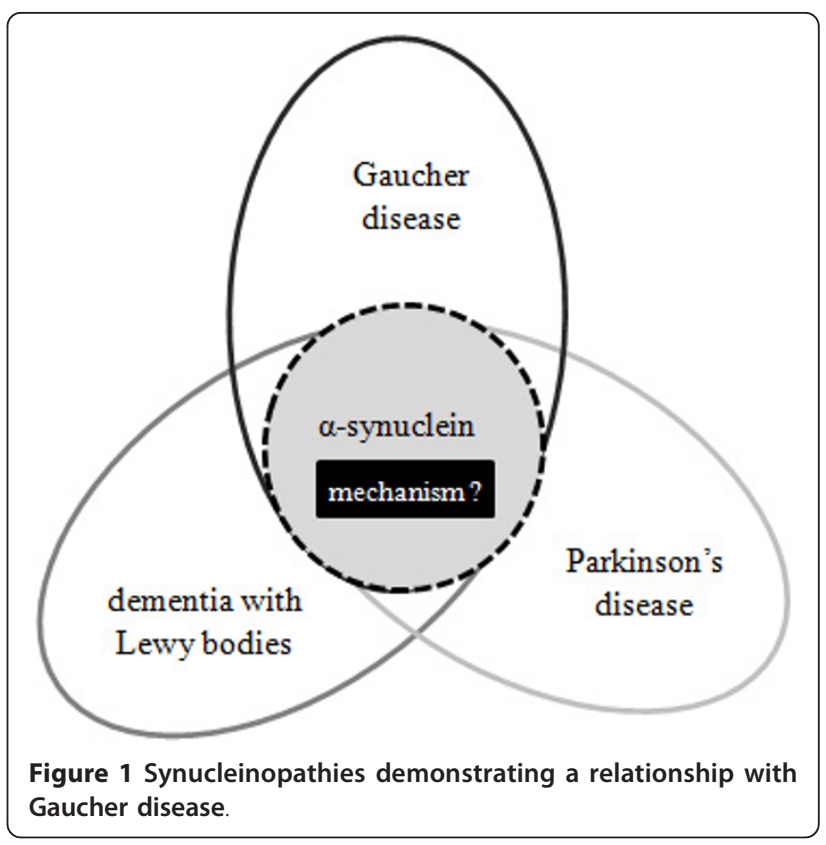

other synucleinopathies such as Parkinson's disease and dementia with Lewy bodies [52-54]. Genetic studies have revealed that variants in the $\alpha$-synuclein-encoding $S N C A$ gene are major risk factors for MSA. Aside from the role of the SNCA gene, however, the etiopathogenesis of MSA has yet to be elucidated: interactions of genetic and environmental factors similar to other complex neurodegenerative diseases are probable [46,55].

Like MSA, neurodegeneration with brain iron accumulation (NBIA) falls under the synucleinopathy umbrella due to various reports of associated $\alpha$-synuclein accumulation $[56,57]$. NBIA comprises a spectrum of progressive extrapyramidal disorders including the previously labelled Hallervorden-Spatz syndrome as well as additional disorders characterized by high levels of iron accumulation in the brain $[58,59]$. Determining whether a patient has NBIA and diagnosing a specific subtype may take several years, while the phenotype and radiographic changes evolve. The major form of NBIA, accounting for approximately $50 \%$ of cases, is pantothenate kinase-associated neurodegeneration (PKAN) caused by mutations in the PANK2 gene [58-60]. Other NBIA disorders, such as aceruloplasminaemia, which is caused by mutations in the $C P$ gene, and neuroferritinopathy, which is caused by mutations in the FTL gene, appear to affect specific, small NBIA sub-populations $[61,62]$. The drive to identify major causative genes has helped refine the NBIA subtypes, providing clinicians with a systematic approach to diagnosing and treating these complex cases [59].

Though both NBIA and MSA are synucleinopathies, they do not exhibit the strong relationship with Gaucher disease seen in patients with Parkinson's disease or 
dementia with Lewy bodies. For NBIA, significant progress was made from 2009 to 2010 in differentiating subtypes according to genetic, radiologic, and clinical findings [63]. However, no correlation with GBA has been mentioned in the resulting literature. Interestingly, most Gaucher patients are anemic due to the presence of splenomegaly. Thus, they may have iron deficiency which could minimize their risk for NBIA. For MSA, numerous analyses have found that GBA mutations are not linked to the disease, suggesting that this branch of the ceramide pathway is unlikely to be associated with all types of primary $\alpha$-synuclein deposition $[41,46,64,65]$. Therefore, for NBIA and MSA patients, there does not appear to be a need for modifying current genetic counselling approaches or for clinicians to perform additional inquiries about possible family members with Gaucher disease.

\section{Mechanism of Interaction}

Exposure of the relationship between Gaucher disease, Parkinson's disease and dementia with Lewy bodies has generated a new challenge: to determine the mechanisms contributing to this association and why such an association does not extend to all synucleinopathies. Both gain-of- and loss-of-function explanations have been proposed [22]. Recently, a prion theory has also been suggested [66].

The gain-of-function theories have in common misfolded mutant glucocerebrosidase as the main culprit. Misfolded GBA has been suggested to contribute to neurodegeneration by inducing lysosomal insufficiency, by impairing autophagic pathways necessary for degrading $\alpha$-synuclein, or by overburdening the ubiquitin-proteasome pathway $[22,67]$. Using cellular and in vivo models, Cullen et al. [68] recently analyzed the effects of wild-type and mutant GBA on $\alpha$-synuclein. Results indicated that GBA mutants promoted $\alpha$-synuclein accumulation in a dose- and time-dependent manner. In cell culture models, the gain-of-function toxic effect was mitigated by rapamycin.

According to the loss-of-function hypothesis, GBA haploinsuffiency might cause its substrate glucocerebroside and other polyunsaturated lipids to accumulate, altering the cell membrane sphingolipid composition. Subsequently, this could disrupt membrane binding of $\alpha$-synuclein, increasing its aggregation in the cytoplasm $[22,69,70]$. Alternatively, elevated levels of glucocerebrosides could cause ryanodine receptor activation, leading to a rise in intracellular free calcium, followed by cell death and parkinsonism [66,71]. Mazzulli et al. [72] recently proposed a more comprehensive mechanism whereby deficient GBA leads to the accumulation of glucocerebroside in neurons that in turn promotes the formation of toxic $\alpha$-synuclein oligomers. Elevated levels of the toxic $\alpha$-synuclein species trigger depletion of lysosomal GBA and further stabilization of the $\alpha$-synuclein oligomers by glucocerebroside accumulation, resulting in a self-propagating positive feedback loop leading to neurodegeneration.

Another theory gaining momentum is the possibility that PD is a prion disorder resulting from amplified production and/or impaired clearance of $\alpha$-synuclein, prompting misfolding and the development of toxic oligomers, aggregates, and cell death. Moreover, it is feasible that $\alpha$-synuclein itself is a prion protein that can selfaggregate and be transmitted to unaffected cells, thus propagating the disease process [73]. The Gaucher cell environment created by mutated glucocerebrosidase could serve as a vehicle to enhance these events [66].

The aforementioned models, however, all exhibit limitations. None can singlehandedly explain why only a fraction of those with $G B A$ mutations actually develop PD or why carriers or patients with null $G B A$ alleles can develop parkinsonian phenotypes. Westbroek et al. [74] suggest that the presence of aberrant glucocerebrosidase and/or subsequent changes in enzyme activity and substrate accumulation add to the pathology of $\alpha$-synuclein in a secondary fashion. Hence, GBA mutations may augment rather than initiate $\alpha$-synuclein pathology. Conversely, Sardi et al. [75] provide in vivo evidence that a single point mutation in $G B A$ can cause $\alpha$-synuclein misprocessing and cognitive deficits characteristic of synucleinopathies. Both enzymatic loss-of-function and toxic gain-of-function mechanisms were found to contribute to the development of the Gaucher-related synucleinopathies, and exogenous administration of glucocerebrosidase corrected the observed pathological features. Interestingly, Choi et al. [76] recently reported that patients with GBA-associated synucleinopathies showed aggregation of oligomeric forms of $\alpha$-synuclein in SDSsoluble brain fractions, while only monomeric forms of $\alpha$-synuclein were present in subjects with $G B A$ mutations without parkinsonism.

\section{Conclusions}

The high frequency of glucocerebrosidase mutations among ethnically diverse cohorts of Parkinson's disease patients render mutations in this gene as one of the most common and universally reported risk factors for PD [22]. It is also clear that a relationship exists between Gaucher disease and dementia with Lewy bodies. However, this association does not appear to extend to all synucleinopathies. Presently, no link has been found between $G B A$ mutations and multiple system atrophy or neurodegeneration with brain iron accumulation.

The clinical implications of this relationship, such as modifications to genetic counseling or testing regimens, will need to be addressed. Hruska et al. [77] recommended that questions regarding parkinsonian symptoms be included in Gaucher patient evaluations and that 
inquiries about relatives with Gaucher disease be made in Parkinson disease clinics. However, caution was advocated in translating the findings to the patient community due to the low combined incidence and the potential to generate alarm.

The mechanism behind the relationship between $G B A$ mutations and PD or DLB remains elusive. Gain-offunction, loss-of-function, and prion theories have been proposed. A better understanding of this link will provide new avenues for investigation, further clarification of synucleinopathy family members, and the development of novel therapies.

\section{List of Abbreviations}

FDA: (US Food and Drug Administration); GBA: (glucocerebrosidase); NAC: (nonamyloid component); PD: (Parkinson's disease); DLB: (dementia with Lewy bodies); REM: (rapid eye movement); MSA: (multiple system atrophy); NBIA: (neurodegeneration with brain iron accumulation).

\section{Acknowledgements and Funding}

This work was supported by Natural Sciences and Engineering Research Council Discovery Grant \#138216-2009 to FYMC.

\section{Author details}

${ }^{1}$ TNC Scientific Consulting, Calgary, AB, Canada. ${ }^{2}$ Department of Biology, University of Victoria, PO Box 3020, Station CSC, Victoria, BC, V8W 3N5, Canada.

\section{Authors' contributions}

TNC was involved in the conception, researching and writing of the manuscript. FYMC provided expert content review. Both authors read and approved the final manuscript.

\section{Competing interests}

A manuscript editing fee was provided to TNC from FYMC's Natural Sciences and Engineering Research Council grant \#138216-2009. No conflict of interest is present.

Received: 23 August 2011 Accepted: 31 January 2012

Published: 31 January 2012

\section{References}

1. Harmanci O, Bayraktar Y: Gaucher disease: new developments in treatment and etiology. World J Gastroenterol 2008, 14:3968-3973.

2. Choy FYM, Campbell TN: Gaucher disease and cancer: concept and controversy. Int J Cell Biol 2011, 2011:Article ID 150450, 6 pages.

3. Beutler E, Grabowski GA: Gaucher disease. In The Metabolic and Molecular Bases of Inherited Disease. Edited by: Scriver CR, Beaudet AL, Sly WS. New York: McGraw-Hill; 2001:3635-3668.

4. Choy FY, Zhang W, Shi HP, Zay A, Campbell T, Tang N, Ferreira P: Gaucher disease among Chinese patients: review on genotype/phenotype correlation from 29 patients and identification of novel and rare alleles. Blood Cell Mol Dis 2007, 38:287-293.

5. Hruska KS, LaMarca ME, Scott CR, Sidransky E: Gaucher disease: mutation and polymorphism spectrum in the glucocerebrosidase gene (GBA). Human Mutation 2008, 29:567-583.

6. Beutler E, Gelbart T, Scott CR: Hematologically important mutations: Gaucher disease. Blood Cell Mol Dis 2005, 35:355-364.

7. de Fost M, Aerts JM, Hollak CE: Gaucher disease: from fundamental research to effective therapeutic interventions. Neth J Med 2003, 61:3-8.

8. Elstein D, Zimran A: Review of the safety and efficacy of imiglucerase treatment of Gaucher disease. J Biologics 2009, 3:407-417.

9. Aerts JM, Yasothan M, Kirkpatrick P: Velglucerase alfa. Nat Rev Drug Discovery 2010, 9:837-838.

10. Lukina E, Watman N, Arreguin EA, Dragosky M, lastrebner M, Rosenbaum $H$, Phillips M, Pastores GM, Kamath RS, Rosenthal DI, Kaper M, Singh T,
Puga AC, Peterschmitt MJ: Improvement in hematological, visceral, and skeletal manifestations of Gaucher disease type 1 with oral eliglustat tartrate (Genz-112638) treatment: 2-year results of a phase 2 study. Blood 2010, 116:4095-4098.

11. Cox TM: Gaucher disease: clinical profile and therapeutic developments J Biologics 2010, 4:299-313.

12. Galvin JE, Lee V, Trojanowski JQ: Synucleinopathies: clinical and pathological implications. Arch Neurol 2001, 58:186-190.

13. Maroteaux L, Campanelli JT, Scheller RH: Synuclein: a neuron-specific protein localized to the nucleus and presynaptic nerve terminal. $J$ Neurosci 1988, 8:2804-2815

14. Clayton DF, George JM: Synucleins in synaptic plasticity and neurodegenerative disorders. J Neurosci Res 1999, 58:120-129.

15. Spillantini MG, Divane A, Goedert M: Assignment of human alphasynuclein (SNCA) and beta-synuclein (SNCB) genes to chromosomes 4q21 and 5q35. Genomics 1995, 27:379-381

16. de Rijk MC, Launer LJ, Berger K, Breteler MM, Dartigues JF, Baldereschi M, Fratiglioni L, Lobo A, Martinez-Lage J, Trenkwalder C, Hofman A: Prevalence of Parkinson's disease in Europe: a collaborative study of populationbased cohorts. Neurologic Diseases in the Elderly Research Group. Neurology 2000, 54(11 suppl 5):S21-S23.

17. Bekris LM, Mata IF, Zabetian CP: The genetics of Parkinson disease. $J$ Geriatr Psychiatry Neurol 2010, 23(4):228-242.

18. Sellbach AN, Boyle RS, Silburn PA, Mellick GD: Parkinson's disease and family history. Parkinsonism Relat Disord 2006, 12(7):399-409.

19. Polymeropoulos MH, Higgins JJ, Golbe LI, Johnson WG, Ide SE, Di lorio G, Sanges G, Stenroos ES, Pho LT, Schaffer AA, Lazzarini AM, Nussbaum RL, Duvoisin RC: Mapping of a gene for Parkinson's disease to chromosome 4q21-q23. Science 1996, 274(5290):1197-1199.

20. Polymeropoulos MH, Lavedan C, Leroy E, Ide SE, Dehejia A, Dutra A, Pike B, Root H, Rubenstein J, Boyer R, Stenroos ES, Chandrasekharappa S, Athanassiadou A, Papapetropoulos T, Johnson WG, Lazzarini AM, Duvoisin RC, Di lorio G, Golbe LI, Nussbaum RL: Mutation in the alphasynuclein gene identified in families with Parkinson's disease. Science 1997, 276(5321):2045-2047

21. Lesage S, Brice A: Parkinson's disease: from monogenic forms to genetic susceptibility factors. Hum Mol Genet 2009, 18(R1):R48-R59.

22. Sidransky E, Nalls MA, Aasly JO, Aharon-Peretz J, Annesi G, Barbosa ER, BarShira A, Berg D, Bras J, Brice A, Chen CM, Clark LN, Condroyer C, De Marco EV, Dürr A, Eblan MJ, Fahn S, Farrer MJ, Fung HC, Gan-Or Z, Gasser T, Gershoni-Baruch R, Giladi N, Griffith A, Gurevich T, Januario C, Kropp P, Lang AE, Lee-Chen GJ, Lesage S, Marder K, Mata IF, Mirelman A, Mitsui J, Mizuta I, Nicoletti G, Oliveira C, Ottman R, Orr-Urtreger A, Pereira LV, Quattrone A, Rogaeva E, Rolfs A, Rosenbaum H, Rozenberg R, Samii A, Samaddar T, Schulte C, Sharma M, Singleton A, Spitz M, Tan EK, Tayebi N, Toda T, Troiano AR, Tsuji S, Wittstock M, Wolfsberg TG, Wu YR, Zabetian CP, Zhao Y, Ziegler SG: Multicenter analysis of glucocerebrosidase mutations in Parkinson's disease. N Engl J Med 2009, 361(17):1651-1661.

23. Goker-Alpan O, Schiffmann R, LaMarca ME, Nussbaum RL, Mclnerney-Leo A, Sidransky E: Parkinsonism among Gaucher disease carriers. J Med Genet 2004, 41:937-940.

24. Halperin A, Elstein D, Zimran A: Increased incidence of Parkinson disease among relatives of patients with Gaucher disease. Blood Cell Mol Dis 2006, 6:426-428.

25. Aharon-Peretz J, Rosenbaum H, Gershoni-Baruch R: Mutations in the glucocerebrosidase gene and Parkinson's disease in Ashkenazi Jews. N Engl J Med 2004, 351:1972-1977.

26. Sato C, Morgan A, Lang AE, Salehi-Rad S, Kawarai T, Meng Y, Ray PN, Farrer LA, St George-Hyslop P, Rogaeva E: Analysis of the glucocerebrosidase gene in Parkinson's disease. Mov Disord 2005, 20:367-370.

27. Toft M, Pielsticker L, Ross OA, Aasly JO, Farrer MJ: Glucocerebrosidase gene mutations and Parkinson disease in the Norwegian population. Neurology 2006, 66:415-417.

28. Tan EK, Tong J, Fook-Chong S, Yih Y, Wong MC, Pavanni R, Zhao Y: Glucocerebrosidase mutations and risk of Parkinson disease in Chinese patients. Arch Neurol 2007, 64:1056-1058.

29. Mata IF, Samii A, Schneer SH, Roberts JW, Griffith A, Leis BC, Schellenberg GD, Sidransky E, Bird TD, Leverenz JB, Tsuang D, Zabetian CP: Glucocerebrosidase gene mutations: a risk factor for Lewy body disorders. Arch Neurol 2008, 65:379-382. 
30. Spitz M, Rozenberg R, Pereira Lda V, Reis Barbosa E: Association between Parkinson's disease and glucocerebrosidase mutations in Brazil. Parkinsonism Relat Disord 2008, 14:58-62.

31. Leverenz JB, Lopez OL, Dekosky ST: The expanding role of genetics in the lewy body diseases: the glucocerebrosidase gene. Arch Neurol 2009, 66(5):555-556.

32. Mitsui J, Mizuta I, Toyoda A, Ashida R, Takahashi Y, Goto J, Fukuda Y, Date H, Iwata A, Yamamoto M, Hattori N, Murata M, Toda T, Tsuji S: Mutations for Gaucher disease confer high susceptibility to Parkinson disease. Arch Neurol 2009, 66:571-576.

33. Neumann J, Bras J, Deas E, O'Sullivan SS, Parkkinen L, Lachmann RH, Li A, Holton J, Guerreiro R, Paudel R, Segarane B, Singleton A, Lees A, Hardy J, Houlden H, Revesz T, Wood NW: Glucocerebrosidase mutations in clinical and pathologically proven Parkinson's disease. Brain 2009, 132(Pt 7):1783-1794.

34. Lesage $S$, Anheim M, Condroyer C, Pollak P, Durif F, Dupuits C, Viallet F, Lohmann E, Corvol JC, Honoré A, Rivaud S, Vidailhet M, Dürr A, Brice A: Large-scale screening of the Gaucher's disease-related glucocerebrosidase gene in Europeans with Parkinson's disease. Hum Mol Genet 2011, 20(1):202-10.

35. McKeith I, Mintzer J, Aarsland D, Burn D, Chiu H, Cohen-Mansfield J, Dickson D, Dubois B, Duda JE, Feldman H, Gauthier S, Halliday G, Lawlor B, Lippa C, Lopez OL, Carlos Machado J, O’Brien J, Playfer J, Reid W: Dementia with Lewy bodies. Lancet Neurol 2004, 3:19-28.

36. Neef D, Walling AD: Dementia with Lewy bodies: an emerging disease. Am Fam Physician 2006, 73:1223-1230.

37. McKeith IG, Galasko D, Kosaka K, Perry EK, Dickson DW, Hansen LA, Salmon DP, Lowe J, Mirra SS, Byrne EJ, Lennox G, Quinn NP, Edwardson JA, Ince PG, Bergeron C, Burns A, Miller BL, Lovestone S, Collerton D, Jansen EN, Ballard C, de Vos RA, Wilcock GK, Jellinger KA, Perry RH: Consensus guidelines for the clinical and pathologic diagnosis of dementia with Lewy bodies (DLB): report of the consortium on DLB international workshop. Neurology 1996, 47:1113-1124.

38. Boeve BF, Silber MH, Ferman TJ, Lucas JA, Parisi JE: Association of REM sleep behavior disorder and neurodegenerative disease may reflect an underlying synucleinopathy. Mov Disord 2001, 16(4):622-30.

39. Mollenhauer B, Forstl H, Deuschl G, Storch A, Oertel W, Trenkwalder C: Lewy body and parkinsonian dementia: common, but often misdiagnosed conditions. Dtsch Arztebl Int 2010, 107(39):684-91.

40. Velayati A, Yu WH, Sidransky E: The role of glucocerebrosidase mutations in Parkinson disease and Lewy body disorders. Curr Neurol Neurosci Rep 2010, 10:190-198.

41. Goker-Alpan O, Giasson BI, Eblan MJ, Nguyen J, Hurtig HI, Lee VM, Trojanowski JQ, Sidransky E: Glucocerebrosidase mutations are an important risk factor for Lewy body disorders. Neurology 2006, 67:908-910.

42. Farrer MJ, Williams LN, Algom AA, Kachergus J, Hulihan MM, Ross OA Rajput A, Papapetropoulos S, Mash DC, Dickson DW: Glucosidase-beta variations and Lewy body disorders. Parkinsonism Relat Disord 2009, 15:414-416.

43. Clark LN, Kartsaklis LA, Wolf Gilbert R, Dorado B, Ross BM, Kisselev S, Verbitsky M, Mejia-Santana H, Cote $\amalg$, Andrews H, Vonsattel JP, Fahn S, Mayeux R, Honig LS, Marder K: Association of glucocerebrosidase mutations with dementia with lewy bodies. Arch Neurol 2009, 66:578-583.

44. Parnetti L, Balducci C, Pierguidi L, De Carlo C, Peducci M, D'Amore C, Padiglioni C, Mastrocola S, Persichetti E, Paciotti S, Bellomo G, Tambasco N, Rossi A, Beccari T, Calabresi P: Cerebrospinal fluid $\beta$-glucocerebrosidase activity is reduced in Dementia with Lewy Bodies. Neurobiol Dis 2009, 34:484-486

45. Balducci C, Pierguidi L, Persichetti E, Parnetti L, Sbaragli M, Tassi C, Orlacchio A. Calabresi P, Beccari T, Rossi A: Lysosomal hydrolases in cerebrospinal fluid from subjects with Parkinson's disease. Mov Disord 2007, 22:1481-1484.

46. Stemberger S, Scholz SW, Singleton AB, Wenning GK: Genetic players in multiple system atrophy: unfolding the nature of the beast. Neurobiol Aging 2011, 32(10):1924.e5-14.

47. Watanabe H, Saito $Y$, Terao S, Ando T, Kachi T, Mukai E, Aiba I, Abe Y, Tamakoshi A, Doyu M, Hirayama M, Sobue G: Progression and prognosis in multiple system atrophy: an analysis of 230 Japanese patients. Brain 2002, 125:1070-1083.
48. Schrag A, Wenning GK, Quinn N, Ben- Shlomo Y: Survival in multiple system atrophy. Mov Disord 2008, 23:294-296.

49. Shimohata T, Ozawa T, Nakayama H, Tomita M, Shinoda H, Nishizawa M: Frequency of nocturnal sudden death in patients with multiple system atrophy. J Neurol 2008, 255:1483-1485.

50. Flabeau O, Meissner WG, Tison F: Multiple system atrophy: current and future approaches to management. Ther Adv Neurol Disord 2010, 3(4):249-263

51. Wenning GK, Stefanova N, Jellinger KA, Poewe W, Schlossmacher MG: Multiple system atrophy: a primary oligodendrogliopathy. Ann Neurol 2008, 64:239-246.

52. Lantos PL: The definition of multiple system atrophy: a review of recent developments. J Neuropathol Exp Neurol 1998, 57:1099-1111.

53. Spillantini MG, Crowther RA, Jakes R, Cairns NJ, Lantos PL, Goedert M: Filamentous alpha-synuclein inclusions link multiple system atrophy with Parkinson's disease and dementia with Lewy bodies. Neurosci Lett 1998, 251:205-208.

54. Wakabayashi K, Yoshimoto M, Tsuji S, Takahashi H: Alphasynuclein immunoreactivity in glial cytoplasmic inclusions in multiple system atrophy. Neurosci Lett 1998, 249:180-182.

55. Brown RC, Lockwood AH, Sonawane BR: Neurodegenerative diseases: an overview of environmental risk factors. Environ Health Perspect 2005, 113:1250-1256

56. Galvin JE, Giasson B, Hurtig HI, Lee VM, Trojanowski JQ: Neurodegeneration with brain iron accumulation, type 1 is characterized by alpha-, beta-, and gamma-synuclein neuropathology. Am J Pathol 2000, 157(2):361-368.

57. Paisan-Ruiz C, Li A, Schneider SA, Holton JL, Johnson R, Kidd D, Chataway J, Bhatia KP, Lees AJ, Hardy J, Revesz T, Houlden H: Widespread Lewy body and tau accumulation in childhood and adult onset dystoniaparkinsonism cases with PLA2G6 mutations. Neurobiol Aging 2010.

58. Hayflick SJ, Westaway SK, Levinson B, Zhou B, Johnson MA, Ching KH, Gitschier J: Genetic, clinical, and radiographic delineation of Hallervorden-Spatz syndrome. N Engl J Med 2003, 348:33-40.

59. Gregory A, Polster BJ, Hayflick SJ: Clinical and genetic delineation of neurodegeneration with brain iron accumulation. J Med Genet 2009, 46(2):73-80.

60. Zhou B, Westaway SK, Levinson B, Johnson MA, Gitschier J, Hayflick SJ: A novel pantothenate kinase gene (PANK2) is defective in HallervordenSpatz syndrome. Nat Genet 2001, 28:345-349.

61. Harris ZL, Takahashi Y, Miyajima H, Serizawa M, MacGillivray RT, Gitlin JD: Aceruloplasminemia: molecular characterization of this disorder of iron metabolism. Proc Natl Acad Sci USA 1995, 92:2539-2543.

62. Curtis AR, Fey C, Morris CM, Bindoff LA, Ince PG, Chinnery PF, Coulthard A, Jackson MJ, Jackson AP, McHale DP, Hay D, Barker WA, Markham AF, Bates D, Curtis A, Burn J: Mutation in the gene encoding ferritin light polypeptide causes dominant adult-onset basal ganglia disease. Nat Genet 2001, 28:350-354.

63. Gregory A, Hayflick SJ: Genetics of neurodegeneration with brain iron accumulation. Curr Neurol Neurosci Rep 2011, 11:254-261.

64. Segarane B, Li A, Paudel R, Scholz S, Neumann J, Lees A, Revesz T, Hardy J, Mathias CJ, Wood NW, Holton J, Houlden H: Glucocerebrosidase mutations in 108 neuropathologically confirmed cases of multiple system atrophy. Neurology 2009, 72:1185-1186.

65. Jamrozik Z, Lugowska A, Slawek J, Kwiecinski H: Glucocerebrosidase mutations p.L444P and p.N370S are not associated with multisystem atrophy, progressive supranuclear palsy and corticobasal degeneration in Polish patients. J Neurol 2010, 257(3):459-60.

66. Goldin E: Gaucher disease and parkinsonism, a molecular link theory. Mol Genet Metab 2010, 101:307-310.

67. Depaolo J, Goker-Alpan O, Samaddar T, Lopez G, Sidransky E: The association between mutations in the lysosomal protein glucocerebrosidase and parkinsonism. Mov Disord 2009, 24(11):1571-1578.

68. Cullen V, Sardi SP, Ng J, Xu YH, Sun Y, Tomlinson JJ, Kolodzeij P, Kahn I, Saftiq P, Woulfe J, Rochet JC, Glicksman MA, Cheng SH, Grabowski GA, Shihabuddin LS, Schlossmacher MG: Acid $\beta$-glucosidase mutants linked to Gaucher disease, Parkinson disease, and Lewy body dementia alter asynuclein processing. Ann Neurol 2011, 69(6):940-953.

69. Jo E, McLaurin J, Yip CM, St George-Hyslop P, Fraser PE: Alpha-Synuclein membrane interactions and lipid specificity. J Biol Chem 2000, 275(44):34328-34334 
70. Velayati A, Yu WH, Sidransky E: The role of glucocerebrosidase mutations in Parkinson disease and Lewy body disorders. Curr Neurol Neurosci Rep 2010, 10(3):190-198.

71. Pelled D, Trajkovic-Bodennec S, Lloyd-Evans E, Sidransky E, Schiffmann R, Futerman AH: Enhanced calcium release in the acute neuronopathic form of Gaucher disease. Neurobiol Dis 2005, 18:83-88.

72. Mazzulli JR, Xu YH, Sun Y, Knight AL, McLean PJ, Caldwell GA, Sidransky E, Grabowski GA, Krainc D: Gaucher disease glucocerebrosidase and asynuclein form a bidirectional pathogenic loop in synucleinopathies. Cell 2011, 146(1):37-52.

73. Olanow CW, Prusiner SB: Is Parkinson's disease a prion disorder? Proc Natl Acad Sci USA 2009, 106:12571-12572.

74. Westbroek W, Gustafson AM, Sidransky E: Exploring the link between glucocerebrosidase mutations and parkinsonism. Trends Mol Med 2011.

75. Sardi SP, Clarke J, Kinnecom C, Tamsett TJ, Li L, Stanek LM, Passini MA, Grabowski GA, Schlossmacher MG, Sidman RL, Cheng SH, Shihabuddin LS: CNS expression of glucocerebrosidase corrects alpha-synuclein pathology andmemory in a mouse model of Gaucher-related synucleinopathy. Proc Natl Acad Sci USA 2011, 108(29):12101-12106.

76. Choi JH, Stubblefield B, Cookson MR, Goldin E, Velayati A, Tayebi N, Sidransky E: Aggregation of a-synuclein in brain samples from subjects with glucocerebrosidase mutations. Mol Genet Metab 2011, 104(12):185-188.

77. Hruska KS, Goker-Alpan O, Sidransky E: Gaucher disease and the synucleinopathies. Biomed Biotechnol 2006, 2006:Article ID 78549, Pages $1-6$.

doi:10.1186/1750-1172-7-12

Cite this article as: Campbell and Choy: Gaucher disease and the synucleinopathies: refining the relationship. Orphanet Journal of Rare Diseases 2012 7:12.

\section{Submit your next manuscript to BioMed Central and take full advantage of:}

- Convenient online submission

- Thorough peer review

- No space constraints or color figure charges

- Immediate publication on acceptance

- Inclusion in PubMed, CAS, Scopus and Google Scholar

- Research which is freely available for redistribution

Submit your manuscript at www.biomedcentral.com/submit 